\title{
Possibility of using Sewage Effluent from Different Water Treatment Plants in Different Cities of Saudi Arabia for Agricultural Reuse
}

\author{
Abdullatif A. Neamatallah \\ Environment Department, \\ Faculty of Meteorology, \\ Environment and Arid Land Agriculture, \\ King Abdulaziz University, Jeddah, Saudi Arabia.
}

\begin{abstract}
A comparative study was conducted to test the efficiencies of 7 sewage water treatment plants, 4 in Jeddah, Bani-Malik, Al-Balad, Al-Khomrah, Hael, one in Makkah, one in Abha and one in Taif city in Saudi Arabia. The plants were installed for the treatment of the cities domestic and industrial wastewater effluent. The parameters studied included the physiological, chemical and biological characteristics treated sewage water (effluent) of the treatment plants. The 7 plants vary in their efficiencies to eliminate the studied parameters. The values of these parameters are within the range allowed according to the standards of the MWE ( 2005 ) and FAO ( 1985 ) except for the total coliform bacteria ( TCB ) which is high than the standards suggested (not to exceed 1000 colonies $/ 100 \mathrm{ml}$ ), and also according to concentrations of TSS and according to concentrations of BOD and COD. So according to these results sewage water treatment plants working now in Saudi Arabia needed modernization to be more efficient in treatment of the raw waste water, so it can be used for irrigation and production of crop, fodder and vegetable plants. It is recommended to resort to treated sewage water for production of field crops, forages in general in Saudi Arabia.
\end{abstract}

Key words: Effluent - water treatment -BOD - COD-field crops

\section{INTRODUCTION}

Saudi Arabia is an arid land country suffering shortage in fresh water for irrigation purposes, a reason that encouraged the Kingdom to search for alternatives, thus started using treated wastewater in agriculture sector. And throughout the world treated sewage water is now used in agriculture due to many benefits accompanying it, such as that it is a fresh water containing high level of organic matter and plant nutrients, (Al-Sha'lan, 2001). Saudi Arabia has more than 30 desalination water treatment plants with daily production of treated water reaching up to 3 million $\mathrm{m} 3 /$ day. Part of this water is reused in agriculture. Irrigation with treated sewage water saved up to $45 \%$ in fertilizers cost for wheat crop and $94 \%$ for alfalfa crop compared to irrigation using well water because it contains the essential plant nutrients, and the yield of these crops by 11 and $23 \%$, respectively, compared to irrigation with well water (Al-Abdulqader and Al-Jaloud (2003).

Due to scarcity of water that can be used in irrigation and production of plant crops most of the countries throughout the world restored to treated sewage water and started using it in irrigation for production of all types of crops, vegetables, seeds, fibers and trees from long time ago, as was shown by Culp et al. , 1978 ; Ongerth and Jopling , 1977 ; and Muller, 1977 (in Germani) , Arceivala,1981 in (India) ,Hart et al.,1977 in (South Africa) ,Brown et al.,in (California), Jurdi et al. ,1981 (in Lebanon), Lau , 1981 (in Hawai), Liu and Zhou 2005 in (China), Emongor and Ramolemana, 2005 (in Botsowana) Most of the vegetable crops in Senegal are irrigated with a mixture of untreated wastewater together with groundwater, and nearly 20 million hectares are irrigated with untreated or partially treated wastewater in the developing countries (Dreschsel, et al., 2002). Well treated wastewater can be used irrigation of crops and produce very healthy crops (Najafi et al., 2003, Jimenez, 2005, Munir and Ayadi 2005, Esmailiyan et al., 2008 and Zavadil, 2009).. Thus it is one of the aims of the Kingdom of Saudi Arabia to start using this source in irrigation of food products and forage production, due to deficiency of irrigation water and reduction of rainwater. Sewage effluents are contaminated and polluted with heavy metals, microbes and different other chemical and biological elements. Sewage water contains both the municipal and the industrial effluents. The organic materials in the sewage water are in the form of nonhomogenous mixture of compounds, most of it is nitrogenous, like urea, proteins, ammo acids, and nonnitrogenous materials like hydrocarbons, lipids, detergents, pesticides and soap residues (Arab Water World, 1995). Evaluation of wastewater for reusing $m$ agriculture has been discussed by many researchers (Abdel Magid, 1996; Arafa et al., 2001; Al-Solaimani and Hashim, 2004; Emongor and Ramolemana, 2005). Abdel Magid (1996), tested the suitability of wastewater and effluent from Unayzah sewage treatment plant for reuse in irrigation and found that the physico- chemical parameters of that water fall within the local and international standards for irrigation reuse, but the total coliform bacteria count (TCB) was high rendering the effluent unacceptable for irrigation use. In another tests by Arafa et al., (2001), they evaluated the population of staphylococcus, coliform and fecal coliform bacteria and yeast and molds of the waste water of Makkah city, and concluded that the sewage water is acceptable for reuse in agriculture. There are some studies assessed the sewage water quality and its dilution at South Cornich in Jeddah City (Mudarries et al., 2006). There are always worries and precaution about the reverse affect of sewage water use in the 
irrigation of field crops for humans and animals (Toze, 2005). Thus, several international and local organizations have concerned about putting standards for sewage water reuse in agriculture. Nitrate is a threatening contaminant element in sewage water if found at high rates (Hallberg and Keeney, 1993). The U. S. Environmental Agency (USEPA) has set a maximum contaminant level for nitrate of $10(\mathrm{mg} / \mathrm{L})$ as nitrogen for drinking water (USEPA, 1991. The aim of this study is to compare the efficiencies of 7 sewage water treatment plants in numbers of Saudi Cities as regards to their capabilities to treat the disposed sewage water and the possibility of using this treated water in agriculture.

\section{MATERIALS AND METHODS}

\section{Sample Collection :}

Treated sewage water samples were collected from the waste water treatment plant at Jeddah (Bani-Malik, Al-Balad, Al-Khomrah and Hail) and waste water treatment plant in Makkah , Al-Taif and Abha. Six waste water samples were collected at the end of April and September 2017 at $10 \mathrm{~cm}$ below the water surface to avoid floating solids. Chemical analysis was performed in Al-Amri Laboratories in Jeddah according to APHA (1985).

Biological analysis was performed at the microbiological lab, Faculty of Science, King Abdulaziz University also according to APHA (1985). Physical and Chemical Analysis of Biological Oxygen Demand (BOD) was measured using Dissolved Oxygen Meter, which measures the quantity of dissolved oxygen in the water sample using dissolved oxygen electrode before and after a five-day incubation period at $20^{\circ}$ C. Total Dissolved Solids (TDS) was evaluated by filtering $50 \mathrm{ml}$ of wastewater through standard glass fiber filter, then oven dried at $1800 \mathrm{C}$. Nitrates (N-No3) were measured using Nesslerization method with spectrophotometer at a wave length of $450 \mathrm{~mm}$. Chlorides $(\mathrm{Cr})$ were evaluated using Argenometric method in which the water samples were titrated against $\mathrm{AgNO} 3$ solution applying potassium chromate as indicator showing the end point of the reaction between silver nitrate and the chloride. Light absorbance of the suspension was measured by spectrophotometer420 nm. For Determination of other elements such as $\mathrm{Fe}, \mathrm{Zn}, \mathrm{Cu}, \mathrm{Cd}$ and $\mathrm{Pb}$ extracted using the perchloric-nitric digestion procedure of Shelton and Harper (1941), and the concentration of these elements were measured using the Atomic Absorption Spectrophotometer model 5000 Perkin Elmer.

\section{Biological Analysis :}

The standard plate count by serial dilution is used in determination of the total number of bacteria in sewage water on nutrient agar plates. For coliform bacteria, the Most Probable Number method was used on McKonkey broth for acid and gas detection.

\section{RESULTS AND DICUSSION PHYSICAL CHARACTERISTICS}

\section{The $p H$ Value:}

The results in table (1), shows that the $\mathrm{pH}$ values of the treated water of 6 of the treatment plants $\mathrm{Al}-\mathrm{Balad}, \mathrm{Al}-$ Khomrah, Hail, Makkah, Al-Taif and Abha are above 7, while that of Bani - Malik is below 7 (6.68). This means that the treated sewage water of the above 6 treatment plants is alkaline in nature, while that of Bani - Malik plant is some what acidic in nature $\mathrm{PH}$ is a logarithmic scale used to determine acidity or alkaline and measures the negativity of hydrogen activity in units per liter of water from hydrogen ions (Bates, 1973). Wallace and Cha (1977) noted that the $\mathrm{pH}$ of wastewater is an important factor in influencing the melting of heavy metals in the soil and thus their availability to the plant. Several previous studies have pointed to the wastewater base in Al-Khomra district south of Jeddah and that the $\mathrm{pH}$ in this water has exceeded 8 units (ROCERSGA, 2010; Al-Farraj et al., 2012). All these treated sewage waters can safely be used in agriculture based on their $\mathrm{pH}$ values.

EC

The results in table (1) show that EC values in Makkah, AlTaif and Abha treated water reached 1130, 1061.44 and 455 $\mathrm{U}$ mhos / cm respectively, and all below standards of (MWE, 2005), (PME, 1989), (FAO, 1985). The degree of electrical conductivity is a numerical indication of the ability of the solution to transfer the electric current and depends on the quality and concentration of the ions in the solution. These ions are often non-salts and the electrical conductivity is expressed in micromes in the centimeter (U mhos / cm). In general, the amount of dissolved salts in water is indicated by the degree of electrical conductivity, which suggests the validity of water for use in different purposes. Accordingly these treated sewage waters can safely be used in agriculture based on their EC values.

Total suspended solids (TSS) and

Total dissolved solids (TDS) :

The total residues found in the sewage water are formed from both the total suspended solids(TSS) and the total dissolved solids (TDS). The sewage water treated by Abha treatment plant contained the least rate of (TSS) amounted to $5 \mathrm{mg} / \mathrm{L}$, while the sewage water treated by Makkah treatment plant contained the highest (TSS) 162 $\mathrm{mg} / \mathrm{L}$, the others gave in between values (table 1). And all these treated sewage water by all these plants except Abha contain TSS above that recommended by (PME, 1989) and (MWE, 2005). TSS is the dry weight of suspended particles that have not been dissolved in water, a parameter used to assess the quality of waste water after and before treatment, and listed as conventional pollutants for clean water. Suspended solids (TSS) cause many problems, they prevent high light from reaching the plant and reduce the process of photosynthesis and thus reduce the dissolved oxygen content in the water and thus affected organisms living in water.

Regarding the total dissolved solids, (TDS) the sewage water treated by Abha plant contained the least level of (TDS) $429 \mathrm{mg} / \mathrm{L}$ compared to the other 6 plants, seconded 
by Bani-Malik (504.32 mg/L ), then Al-Taif (859 mg/L), then Makkah $(868 \mathrm{mg} / \mathrm{L})$ and then Al-Balad $(1752 \mathrm{mg} / \mathrm{L})$, Al-Khomrah (1813 mg/L) and the last is Hail (1987 mg/L). So in this respect Abha, Bani-Malak, Makkah and Al-Taif plants are more efficient compared to the other 3 treatment plants, giving treated water with a level of TDS less than that suggested by both MWE (2005) and PME (1989), but also these 3 plants Hail, Al-Khomrah and Al-Balad gave treated water with TDS less than that put forward by FAO (1985).

- Biochemical oxygen demand (BOD)

- $\quad$ And chemical oxygen demand (COD):

The biochemical oxygen demand (BOD) and the chemical oxygen demand (COD) indicate the quantity of the organic materials that are capable of being decomposed by aerobic bacteria in an incubation period for 5 days at temperature $20 \mathrm{C}$, and its quantity in the sewage water refers to the quantity of oxygen demanded for its decomposition. From the results in (table 1) Abha and $\mathrm{Al}=$ Taif treated sewage water gave the least level of BOD (10.7 and $12.16 \mathrm{mg} / \mathrm{L}$ ), showing they are more efficient in this respect compared to the other 5 plants, followed by Makkah with $(54 \mathrm{mg} / \mathrm{L})$, then Al- Khomrah treatment with $(56.53 \mathrm{mg} / \mathrm{L})$, Bani- Malik with $(77.0 \mathrm{mg} / \mathrm{L})$, then Al-Balad with $(79.59 \mathrm{mg} / \mathrm{L})$ and last is Hail with the highest BOD level $(88.98 \mathrm{mg} / \mathrm{L})$. Abha and Al-Taif treated sewage water are permissible for use in agriculture because they contain BOD below the standard of PME(1989) which is $25 \mathrm{mg} / \mathrm{L}$. And with regard to the chemical oxygen demand (COD) again it is the treated sewage water of Abha and Taif that gave the lowest level of concentration which is 29.9 and $36.77 \mathrm{mg} / \mathrm{L}$ respectively, then Al-Khomrah with $123.53 \mathrm{mg} / \mathrm{L}$, then Makkah with $184 \mathrm{mg} / \mathrm{L}$, and Bani-Malik with $(215 \mathrm{mg} / \mathrm{L})$, and Hail $(238.37 \mathrm{mg} / \mathrm{L})$ and the last is Al- Balad with $(246.18$ $\mathrm{mg} / \mathrm{L})$, respectively. For COD content Abha, Al-Taif and Al-Khomrah plants were the most efficient compared to the other plants giving COD levels less than that suggested by PME (1989) and MWE (2005), while all the other 4 plants are not so efficient in this regard giving COD levels above the proposed standards, table (1). These results indicate that Abha, Taif and Al-Khomrah sewage treated water can be used in agriculture.

Table (1): Mean concentrations of different components in the sewage water treated by the 7 treatment plants Bani- Malik, Al-Balad, AlKhomrah, Hail, Makkah, Al-Taif and Abha

\begin{tabular}{|c|c|c|c|c|c|c|c|c|c|c|}
\hline & pH & TSS & TDS & BOD & COD & $\mathrm{Cl}$ & No3- & $\mathbf{N a}+$ & SAR & TCB \\
\hline Bani-Malik & 6.68 & 105 & 504.32 & 77 & 215 & 430 & 8.5 & 237 & 6.35 & 18000 \\
\hline Al-Balad & 7.9 & 104.8 & 1752 & 79.59 & 246.18 & 572 & 1.22 & 451.82 & 9.56 & 54000 \\
\hline Al-Khomrah & 7.8 & 68.95 & 1813 & 56.50 & 123.53 & 661 & 1.39 & 498.0 & 10.4 & 14000 \\
\hline Hail & 7.35 & 113.8 & 1987 & 88.98 & 238.37 & 647 & 9.8 & 575.62 & 12.02 & \\
\hline Makkah & 8.1 & 162 & 868 & 54 & 184 & 81 & 42 & 398 & 4.1 & $>2400$ \\
\hline Al-Taif & 7.36 & 26.65 & 849 & 121.16 & 36.729.91 & & 24.48 & 20.51 & 5.45 & 1212778 \\
\hline Abha & 8.4 & 5 & 429 & 10.7 & & 79 & 19.1 & 57.8 & 2.58 & \\
\hline M.W.E* & 6-8.4 & 10 & 1500 & 10 & 150 & 600 & 45 & & & 1000 \\
\hline FAQ & $6-9$ & & 2000 & & & 1100 & 1100 & 900 & 15 & 1000 \\
\hline
\end{tabular}

* Ministry of water and Electricity, Saudi Arabia, 2005. * FAO, 1985

\section{Macro-elements: Chlorine ions $\mathrm{Cl}$ - :}

Chlorine ion contents $\mathrm{Cl}-$ ) of the treated sewage water were the lowest in Makkah (67 mg*L), then Abha (79 $\mathrm{mg} / \mathrm{L})$, then comes Bani-Malik treatment plant (430 mg/L), Al-Balad plant ( $572 \mathrm{mg} / \mathrm{L}$ ), then Al-Khomrah with( 580 $\mathrm{mg} / \mathrm{L})$ and the highest was in Hail treatment plant (647 $\mathrm{mg} / \mathrm{L}$ ), and all these rates are below that suggested by FAO (1985) and MWE (2005), except Hail treatment plant which is below that suggested by MWE (2005), table (1). According to the US Environmental Protection Agency, high concentrations of chloride are harmful and toxic to aquatic animals and plants. The Pollution Control Agency of Minnesota (MPCA, 2018) has established standards for chloride concentration in wastewater. The 4 day average exposure is standard $230 \mathrm{mg} / \mathrm{L}$, and for short day exposure the standard can reach $860 \mathrm{mg} / \mathrm{L}$. Therefore, according to these measures the concentration of chloride in treated sewage water in these plants is not high, and thus can safely be used in agriculture.

Nitrate ions ( NO3- ):

More than $90 \%$ of the nitrogen present in sewage water is in the form of ammonia or its components. Recently the nitrogen compounds in the sewage water were considered one of the most important environmental concern due to the environmental problems accompanying these compounds, and one of them is their toxic effects on fishes and the other aquatic organisms, and activation of the dissolved oxygen in water. Consequently, abundance of nitrogen in sewage water is beneficial to plants.

Table (1) illustrates that the treated sewage water of AlBalad and

Al-Khomrah recorded the least content of NO-3 and 1.39

$\mathrm{mg} / \mathrm{L})$ respectively, then Bani-Malik and Hail have recorded the $(8.5$ and $9.8 \mathrm{mg} / \mathrm{L})$ respectively in their water, then comes Abha Al-Taif and Makkah with 19.1, 24.48 and $32 \mathrm{mg} / \mathrm{L}$ respectively. All of the treatment plants treated sewage water with NO-3 contents at rates below that suggested by MWE (2005), so it can be said that they are accepted for being reused in agriculture .

Sodium ions $(\mathrm{Na}+)$ :

Sodium is a soluble element which is difficult to remove 
through treatment, and its increase in the sewage water is harmful to plants (Russell et al., 1970), and irrigation with water rich in $\mathrm{Na}$ changes the soil to alkaline soil (Takashi, 1985). The results in table (1) indicate that sewage water treated by Makkah and Abha plants gave the least level of $\mathrm{Na}+(20.51$ and $57.8 \mathrm{mg} / \mathrm{L})$, then comes Bani-Malik plant with $(237 \mathrm{mg} / \mathrm{L})$, Al-Taif with $(398 \mathrm{mg} / \mathrm{L})$, while the other plants Al-Balad, Al-Khomrah and Hail record (451.82, 498.0 and $575.62 \mathrm{mg} / \mathrm{L}$ ) respectively. All the $\mathrm{Na}+$ levels in the water treated by the 7 treatment plants are below the level permissible by FAO (1985) for agricultural reuse. These low values of $\mathrm{Na}+$ in these treated sewage water render it legible for use in irrigation of agricultural fields.

Total coliform bacteria (TCB):

The elimination of pathogens $1 \mathrm{~s}$ the main objective in treatment of sewage water for its use or getting rid of it in the sea (WHO, 1979,1973); Mecoy (1969); Entern et al., (1998). And mostly we express the suitability of the sewage water for use according to the maximum permissible concentration of TCB. The results in table (1) show that the highest concentration level of TCB is in the sewage water treatment of Al-Balad plant which gave (54000 colonies $/ 100 \mathrm{~mL})$ but the treated sewage water with the least concentration level of TCB is Al-Taif with only (963 colonies/ 100mL). All treatment plants except Makkah plant gave treated water with TCB levels above that permissible by MWE (2005) and FAO (1985). Therefore these treated waters by these 7 plants can not be recommended for agricultural use, as the total coliform bacterial number that are allowed according to the FAO and MWE standards is $1.0 \times 103$ and $1.8 \times 103$ MPN/100 $\mathrm{ml}$ respectively.
Sodium adsorption ratio (SAR):

Sodium adsorption ratio refers to the ratio of the monovalent cations represented by $\mathrm{Na}$ and the bivalent cations represented by $\mathrm{Ca}$ and $\mathrm{Mg}$. The lowest level of SAR was in the sewage water treated by Abha plant $(2.58 \mathrm{mg} * \mathrm{~L})$, then Makkah $(4.10 \mathrm{mg} / \mathrm{L})$, Bani-Malik plant $(5.35 \mathrm{mg} / \mathrm{L})$ ,and the last was Hail plant with the highest SAR ( 12.02 $\mathrm{mg} / \mathrm{L}$ ), table (1). All the values of SAR in the sewage water treated by all of the 7 treatment plants fall below the permissible level suggested by FAO (1985), and so they are safe and can be reuse in agricultural fields irrigation.

\section{The heavy metals:}

The heavy metals or the micro-elements are important plant nutrients, but the toxic elements have toxic effects on plants, animals and humans. And the micro-elements become toxic and retarding to plant growth if their concentrations in water reached values higher than that permissible for agricultural use. The elimination of these elements from sewage water is practiced by advanced technical methods, like eliminating salts by irreversible collision or ionic exchange. The concentrations of the heavy metals ( $\mathrm{Fe}, \mathrm{Mn}, \mathrm{Cu}, \mathrm{Zn}, \mathrm{Cd}, \mathrm{Pb}, \mathrm{Ni})$ in the treated sewage water plants is shown in table (2).

\section{a) The micro-elements:}

The micro-elements are essential nutritive elements in plants, but are not required at high concentrations when treated water is used in irrigation, due to their harmful effects on humans and animals.

Table (2): Mean concentrations of heavy metal in the sewage water treated by the 7 treatment plants Bani-Malik, Al-Balad, Al-Khomrah and Hail,Al-Taif,

\begin{tabular}{|c|c|c|c|c|c|c|c|}
\hline & $\mathrm{Fe}++$ & $\mathrm{Mn}+$ & $\mathrm{Cu}+$ & $7 n++$ & $\mathrm{Cd}++$ & $\mathbf{P b}+\mathbf{t}$ & $\mathbf{N i + +}$ \\
\hline Bani-Malik & 0.187 & 0.102 & 0.008 & 0.068 & 0.010 & 0.0209 & 0.009 \\
\hline Al-Balad & 0.53 & 0.0745 & 0.01282 & 0.02109 & 0.00027 & 0.0097 & 0.0093 \\
\hline Al-Khomrah & 0.69 & 0.483 & 0.0055 & 0.0114 & 0.00086 & 0.0424 & 0.0083 \\
\hline Hail & 0.16 & 0.94 & 0.0128 & 0.0039 & 0.00009 & 0.0034 & 0.0098 \\
\hline Makkah & 3.1 & 0.56 & 0.26 & 4.69 & 0.004 & 2.7 & 0.25 \\
\hline Al-Taif & 0.186 & 0.069 & 0.008 & 0.091 & 0.007 & 0.015 & 0.011 \\
\hline Abha & 0. & 0.4 & 0.035 & 0.085 & 0.01 & 0.04 & 0.035 \\
\hline M.W.E* & 5 & 0.02 & 0.04 & 4 & 0.01 & 0.01 & 0.02 \\
\hline FAO & 5 & 0.2 & 0.01 & 2 & 0.01 & 0.50 & 0.1 \\
\hline
\end{tabular}

\section{$\operatorname{Iron}(\mathrm{Fe}++)$ :}

The concentration levels of $\mathrm{Fe}++$ in all of the sewage treated by all of the 7 plants are below that levels suggested by MWE (2005) and FAQ (1985), table (2).

\section{Manganese $(\mathrm{Mn++})$ :):}

All of the $\mathrm{Mn}++$ concentrations in the water treated by all the plants are below that levels suggested by FAQ (1985), and by MWE (2005) with exception of Makkah plant.

\section{Copper $(\mathrm{Cu}++)$ :}

The sewage water treated by Al-Khomrah have the lowest $\mathrm{Cu}++$ concentrations $(0.0055 \mathrm{mg} / \mathrm{L})$, seconded by Bani-Malik and Al-Taif with $(0.008$ $\mathrm{mg} / \mathrm{L})$, then Al-Balad and Hail with the same concentrations $(0.0128 \mathrm{mg} / \mathrm{L})$, then Abha with $(0.035$ $\mathrm{mg} / \mathrm{L})$, and Makkah (0.26 mg/L). All of the treatment plants except Makkah gave treated water with concentrations of $\mathrm{Cu}++$ less than the level suggested by MWE (2005), but for the level suggested by FAQ (1985) Al-Balad and Hail plants treated water with high level of $\mathrm{Cu}++$ concentrations.

$$
\text { Zinc }(z n++:) \text { : }
$$

The concentration of $\mathrm{Zn++}$ in the water treated by Hail plant was the lowest $(0.0039 \mathrm{mg} / \mathrm{L})$, seconded by Al-Khomra plant $(0.0114 \mathrm{mg} / \mathrm{L})$, then Al-Balad plant $(0.02109 \mathrm{mg} / \mathrm{L})$, then Bani-Malik with the highest $\mathrm{Zn}++$ concentration $(0.068 \mathrm{mg} / \mathrm{L})$, then Abha $(0.085 \mathrm{mg} / \mathrm{L} 0$, then Al-Taif $(0.091 \mathrm{mg} / \mathrm{L})$, then Makkah (4.69 mg/L) and all of these concentrations are below that levels suggested by MWE (2005) and FAO (1985). The waters can be 
used in agriculture.

b) The toxic metals:

As mentioned their presence in treated sewage water at levels lighter than those suggested by local and international organizations is harmful for use in agricultural purpose.

\section{Cadmium ( $\mathrm{Cd}++$ : : :}

Sewage water treated by Hail plant contained the least $\mathrm{Cd}++$ concentration $(0.00009 \mathrm{mg} / \mathrm{L})$, seconded by Al-Balad with $(0.00027 \mathrm{mg} / \mathrm{L})$, then Al-Khomrah $(0.00086 \mathrm{mG} / \mathrm{L})$ and the last is Bani Malik with the highest $\mathrm{Cd}++$ concentration $(0.010 \mathrm{mg} / \mathrm{L})$ and in case of Makkah Al;-Taif and Abha concentrations are (0.004, 0.007 and $0.01 \mathrm{mg} 7 \mathrm{~L}$ ) respectively.. The 7 treatment plants treated sewage water with values of $\mathrm{Cd}++$ below that values suggested by MWE (2005) and FAO (I 985), so water can be used in agriculture.

$$
\text { Lead }(P b++:) \text { : }
$$

The sewage water treated by Hail plant have the least $\mathrm{Pb}++$ concentration $\quad(0.0034 \quad \mathrm{mg} / \mathrm{L})$, second by Al-Balad with $(0.0097 \mathrm{mg} / \mathrm{L})$, then Al-Khomrah $(0.0414 \mathrm{mg} / \mathrm{L})$, Bani-Malik with $(0.209 \mathrm{mg} / \mathrm{L})$, then Makkah, Al-Taif and Abha with (2.7, 0.015 and $0.04 \mathrm{mg} / \mathrm{L})$. All of the 7 treatment plants treated sewage water with $\mathrm{Pb}++$ concentrations less than the concentrations suggested by FAO (1985) and accordingly water can be used in agriculture.

$$
\text { Nickle }(\mathrm{Ni++}) \text { : }
$$

All of the 7 treatment plants recorded levels of $\mathrm{Ni++}$ below that suggested by MWE (2005) and FAO (1985) except Makkah. So water treated by 6 of these plants is safe and can easily be reused for irrigating field crops for production of forages , crops and vegetables.

Table ( 3 ) : The standards of the studied parameters put forward by the Ministry of Water and Electricity, Department of

\begin{tabular}{|c|c|c|c|}
\hline Element & Ministry of Water and Electricity & $\begin{array}{lc}\text { Department } & \text { of } \\
\text { Meteorology } & \text { and Envirnment Protection }\end{array}$ & FAO \\
\hline PH & $6-8.4$ & $6-9$ & $6.5-8.5$ \\
\hline $\mathrm{Na}(\mathrm{mg} / \mathrm{L})$ & & & 900 \\
\hline NO3(mg/L) & 45 & & \\
\hline $\mathrm{Cl}(\mathrm{mg} / \mathrm{L})$ & 600 & & 1100 \\
\hline $\mathrm{Fe}(\mathrm{mg} / \mathrm{L})$ & 5.0 & & 5.0 \\
\hline $\operatorname{Mn}(\mathrm{mg} / \mathrm{L})$ & 0.02 & 0.001 & 0.2 \\
\hline $\mathrm{Zn}(\mathrm{mg} / \mathrm{L})$ & 4.0 & & 2.0 \\
\hline $\mathrm{Cu}(\mathrm{mg} / \mathrm{L})$ & 0.04 & 0.02 & $\mathbf{0 . 0 1}$ \\
\hline $\mathrm{Pb}(\mathrm{mg} / \mathrm{L})$ & 0.01 & 1.0 & 5.0 \\
\hline $\mathrm{Cd}(\mathrm{mg} / \mathrm{L})$ & 0.01 & 0.02 & 0.01 \\
\hline $\mathrm{Ni}(\mathrm{mg} / \mathrm{L})$ & $\mathbf{0 . 0 2}$ & 0.05 & 0.2 \\
\hline TDS(mg/L) & 1500 & & 2000 \\
\hline TSS(mg/L) & 10 & 15 & \\
\hline COD(mg/L) & 150 & & \\
\hline Total $\quad$ Coliform Bacteria(MPE/100L & 1000 & & 1000 \\
\hline
\end{tabular}
Meteorology and Environment Protection, and FAO

\section{CONCLUSION}

With regard to the physical parameters, the chemical parameters and the macro-elements, the values of the parameters studied in this research concerning their concentrations in the water treated by the 7 treatment plants ,Bani-Malik, Al-Balad, AlKhomrah, Hail, Makkah, Al-Taif and Abha are within the range allowed according to the standards of the MWE ( 2005 ) and FAO ( 1985 ) except for the total coliform bacteria ( TCB ) which is high than the standards allowed by these organizations, (not to exceed 1000 colonies $/ 100 \mathrm{ml}$ ), and also according to concentrations of TSS with exception of Abha, and according to BOD and COD with exception of Albaha and Al-Khomrah treatment plants. So according to these results the water treated by these 7 sewage treatment plants can easily and safely be used for irrigation of agricultural fields as regard their concentrations of $\mathrm{pH}, \mathrm{EC}$, chlorides, nitrates (NO3), $\mathrm{SAR}, \mathrm{Na}, \mathrm{Fe}, \mathrm{Mn}, \mathrm{Cu}, \mathrm{Zn}, \mathrm{Cd}, \mathrm{Pb}, \mathrm{Ni}$, TSS and TDS (except Abha), , BOD and COD (except Abha and
Al-Khomrah. But are not recommended for agricultural reuse as regard to their concentrations of the total coliform bacteria ( TCB).

\section{REFERENCES}

[1] Abdel Magid, H.M. (1996). Quality appraisal of effluent from Unayzahcity wastewater treatment plant for irrigation reuse. JKAU: Met. Env.Arid Land Agric. Sci, 7: 2 1-30.

[2] Agriculture and Aquaculture - Measure for Public Health Protection. World Health Organization, Geneva. agriculture in Saudi Arabia, paper presented at The Sixth Gulf Water Conference held by the Water Science and Technology Association in Riyadh, Kingdom of Saudi Arabia, in 8 - 12 March, 2003.

[3] AI-Solaimani, S. G. and M. Hashim (2004) Influence of wastewater land disposal on the chemical composition of Bormuda Grass grown along the discharge stream in arid land area. Cairo Univ. Stud. Rev. 26: 13-33.

[4] Al-Abdulqader, M.A. and A.A. Al-Jaloud (2003). Economics of using treated sewage water in

[5] Al-Farraj, S.; A. El-Gendy: S. Al-Kahtani: M. El-Hedeny (2012) The impact of sewage pollution on polychaetes of Al Khumrah, South of Jeddah Saudi Arabia. Research Journal of Environmental Sciences, $6: 77-87$.

[6] Al-Sha'lan, S.I. (2001). Effect of treated sewage water on water 
movement in soil using undersurface irrigation system. A project funded by KACST, \#AI 10-20, Riyadh, Saudi Arabia.

[7] APHA (American Public Health Association). 2005. Standard Methods for theExamination of water and waste water. American Pubic Health Association, Washington, DS.

[8] Arab Water World. (1995).Waste water Treatment Project in Lebanon. Beirut, Lebanon. 5(6):42-47.

[9] Arafa, AS., M.H. Hashem, S.J. El-Solimani and M.S. Azroe (2001).Influence of time of the year and location on the wastewater stream onmicrobial characteristics of treated wastewater from the holy city ofMakkah. Env. Arid Land Agric. Sci, 12: 55-81.

[10] Arcievala, s. j. (1977). Water reuse in India. In; Water renovation and reuse, Ed. H . I .shuval, Acad ,press 1977. pp. 277-309.

[11] Bates, Roger G. (1973).Determination of $\mathrm{pH}$ : theory and practice. Wiley, 1973.

[12] Brown, J.W., Thornton, J.P. and Takashi, A. \{1981) Evaluation of agriculture irrigation projects using reclaimed municipal water. Water Reuse Symposium Proceeding. Vol.2, pp.1007-8.

[13] Culp ,R. L. ; G. M. Wesner and Clup ( 1978) Handbook of advanced waste water treatment; 2 nd ed. Pub. V. N. R., Company.

[14] Dreschsel, P. Blumenthal, U.J. and Keraita B. (2002). Balancing health and livelihoods. Adjusting wastewater irrigation guidelines for resource-poor countries. Urban Agriculture Magazine. 8: 7-9.

[15] Emongor, V.E., G.M. Ramolemana (2005). Treated sewage effluent(water) potential to be used for horticultural production $\mathrm{m}$ Potswana.Physics and Chemistry of Earth, 29: 1 101-1 108.

[16] FAO (1985). Water quality for agriculture. FAQ irrigation and drainage.Paper\#29 Rev. 1

[17] Hallberg, G.R., and D.R. Keeney. (1993). Nitrate. In Regional Ground- Water Quality,W.J. Alley (ed.). Van Nostrand Reinhold, New York, pp. 297-322.

[18] Hart, 0. O.; Vuuren, R. J. And Van, (1977). Water reuse in South Africa. In: Water renovation and reuse. Ed. H.I. Shuval, Acad. Press, 355- 394

[19] Jimenez B. (2005). Treatment technology and standards for agricultural wastewater reuse: a case

[20] Jurdi, M.; soufi, M.; and Acra A. (1981). Wastewater reclamation by hydroponic plant growth, Water reuse symposium proc. Vol, 2. pp. 1047-1051.

[21] Lau, L.S. (1981\} Wastewater use for irrigation: A case history in Hawaii.

[22] Liu, Q. and Zhou, L.H. (2005). Primary study on interrelationbetween plant communities and environmental factors in the north Shore of Qinghai Lake. Acta Bot. Sinica, 38: 887-89.

[23] Mara D.D. and Cain-Cross S. (1989): Guidelines for the Safe Use of Wastewater and Excreta in

[24] Ministry of Waters and electricity (MWE), Department of Soil Management (1 985). Saudi Arabian Soil Maps, Kingdom of Saudi Arabia.

[25] Minnesota Pollution Control Agency (MPCA) (2018). Alternatives for addressing chloride in wastewater effluent . 520 Lafayette Road North | Saint Paul, MN 55155-4194.

[26] Mudarris, M. S. A. and Turki A. J. (2006). Sewage Water Quality and its Dilution inthe Costa! Waters of South Corniche, Jeddah, Red Sea, JKAU, Met., Env. \&Arid Land Agric. SeL, Vol 17 No. 2, PP: $115-128$.

[27] Muller, W. J. (1977) Water reusein the federal republic of Germany. In: water renovation and reuse. Ed. H. I. Shuval, Acad. Press, p. 219- 250

[28] MWE (Ministry of water and Electricity) 2005. National wastewater Regulations,Section III -2.2 and 3.2.3 Riyadh, Saudi Arabia.

[29] Najafi P., Mousavi S.F., Feizy F. (2003). Effects of using treated municipal wastewater in irrigation of tomato. In: Proc. ICID 20th European Regional Conf. Montpellier, September 14-19, 2003, 8.

[30] Ongerth, A. J. and jobling, W. F. (1977). Water reuse in California. In: water renovation and reuse. Ed. H.I. Shaval. Acad. Bress. 1977. p.219-225.

[31] Shelton, W. R. and H. J. Harper (1941). A rapid method for thedetermination of total phosphorus in soil and plant material. IowaState College Journal of Sci. 15:403-413.

[32] study in Mexico. Journal of Irrigation and Drainage Engineering ASCE, 54: 23-33. Management,93: 65-72.

[33] Toze, S. (2005). Reuse of effluent water-benefits and risks. Agricultural Water Management. 80: 147-159.
[34] U.S. Environmental Protection Agency. (1991). National Primary Drinking Water Regulations. Synthetic Organic Chemicals and Inorganic Chemicals; Monitoring for Unregulated Contaminants; National Primary Drinking Water Regulations Implementation; National Secondary Drinking Water Regulations. Final Rule. Federal Register 56:20:3526.

[35] Wallace, A. and Cha., J.W. (1977) Trace metals in two garden products derived from sewage sludge. Div. of Environ. Biol., Lab. Of Nuclear Medicine and Radiation Biol. California Univ., Los Angeles. C.A., 90024, USA. Communication in Soils Science and Plant Analysis, 8:819-829.

[36] Water Reuse Symposium Proceeding. Vol. 2, pp. 935-46 